\title{
In vivo callus formation on the surface of tubers of Manchu tubergourd (Thladiantha dubia, Cucurbitaceae)
}

Shvets D.Yu. ${ }^{1}$, Kuluev B.R. ${ }^{1,2}$

${ }^{1}$ Bashkir State University, Ufa, Russia; ${ }^{2}$ Institute of Biochemistry and Genetics - Subdivision of the Ufa Federal Research Centre of the Russian Academy of Sciences, Ufa, Russia

E-mail: shvetsdasha99@yandex.ru

Key message. For the first time, shingles of callus-like structures were found in Thladiantha dubia. Of these formations, shoots and roots are intensively regenerated in vivo. Such a mechanism underlies the active vegetative propagation and wide distribution of this invasive species.

Keywords: invasive species, callus, callus formation, Manchu tubergourd, vegetative propagation.

Thladiantha dubia Bunge (Manchu tubergourd) is a perennial herb from the Cucurbitaceae family, which has a high invasive potential in anthropogenically disturbed areas. This is mainly due to the increased ability of this plant to intensive vegetative propagation through tubers. The characteristics of $T$. dubia tubers that allow this plant to multiply intensively remained unknown. Therefore, the aim of our work was to study shoot formation and root formation on the surface of slices of T. dubia

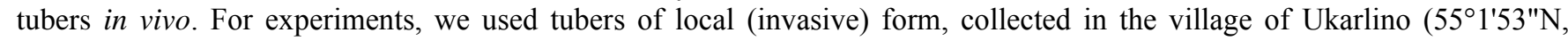
$56^{\circ} 29^{\prime} 3^{\prime \prime E}$.) of the Republic of Bashkortostan (Russia). Two months after harvesting, the tubers were washed with warm soapy water, then tap water and rinsed 2-3 times with distilled water. Each tuber was divided into 3-4 pieces and placed in 200 ml vessels with moistened filter paper and closed with a plastic lid on top. Vegetation vessels were stored in a light room at a temperature of $25^{\circ} \mathrm{C}$ and a light intensity of 4 klux.

As a result of our work, we first discovered a new type of callus-like structures formed on the surface of both native and cut tubers in invasive forms of T. dubia. After one week of incubation, it was from these callus-like structures that both shoots and roots began to regenerate. Cutting the tubers into small pieces had a stimulating effect on the formation of such structures. From almost every callus-like structure, the intensive formation of shoots and roots occurred, and the number of the latter was always less.

Based on our data, it can be suggested that the $T$. dubia is vegetatively propagated by small pieces of tubers due to the ability to induce organogenesis on the surface of tubers through the formation of callus-like structures. We suggest that it is such a feature that allows this species to spread rapidly in cultivated lands.

\section{Каллусообразование in vivo на поверхности клубней тладианты сомнительной (Thladiantha dubia, Cucurbitaceae) Швец Д.Ю. ${ }^{1}$, Кулуев Б.Р. ${ }^{1,2}$ \\ ${ }^{1}$ Башкирский государственный университет, Уфа, Россия; ${ }^{2}$ Институт биохимии и генетики - обособленное структурное подразделение Федерального государственного бюджетного научного учреждения Уфимского федерального исследовательского центра Российской академии наук, Уфа, Россия}

Аннотация. Bпервые у Thladiantha dubia обнаружены опоясывающие каллусоподобные структуры, из которых 6 условия іп vivo интенсивно регенерируют побеги и корни. Такой механизм лежит в основе активного вегетативного размножения и широкого распространения данного инвазионного вида растений.

Ключевые слова: вегетативное размножение, инвазионный вид, каллус, каллусообразование, тладианта сомнительная.

Тладианта сомнительная (Thladiantha dubia Bunge) - многолетнее травянистое растение из семейства тыквенных (Cucurbitaceae), обладающее довольно высоким инвазионным потенциалом на антропогенно-нарушенных территориях. Это обуславливается, главным образом, повышенной способностью этого растения к интенсивному вегетативному размножению через клубни. Особенности клубней $T$. dubia, которые позволяют этому растению интенсивно размножаться, оставались неизвестными. Исходя из этого, целью нашей работы было изучение побего- и корнеобразования на поверхности кусочков клубней T. dubia в условиях in vivo. Для опытов были использованы клубни местной (инвазионной) формы, собранные в селе Укарлино (55²'53" с. ш. 56²9'3"в. д.) Республики Башкортостан. Через два месяца после сбора клубни промывали теплой мыльной водой, затем водопроводной и 2-3 раза споласкивали дистиллированной водой. Каждый клубень разделяли на 3-4 кусочка и помещали в сосуды объемом 200 мл с увлажненной фильтровальной бумагой и сверху закрывали пластиковой крышкой. Вегетационные сосуды держали в световой комнате при температуре $25^{\circ} \mathrm{C}$ и интенсивности света около 4 клк.

В результате нашей работы, впервые обнаружен новый тип каллусоподобных структур, образующихся на поверхности как нативных, так и разрезанных клубней у инвазионных форм T. dubia в условиях in vivo. Через одну неделю инкубации именно из этих каллусоподобных структур начинали регенерировать как побеги, так и корни. Разрезание клубней на маленькие кусочки оказывало стимулирующее влияние на образование каллусоподобных структур. Почти из каждой каллусоподобной структуры происходило интенсивное формирование побегов и корней, причем количество последних всегда было меньше.

На основании наших данных можно предположить, что тладианта сомнительная активно размножается вегетативно небольшими кусочками клубней благодаря способности индуцировать органогенез на поверхности клубней через образование каллусоподобных структур. Мы полагаем, что именно такая особенность позволяет данному виду стремительно распространяться в обрабатываемых человеком землях. 